\title{
IMPACT OF COVID - 19 ON CONSUMER BEHAVIOUR IN E-COMMERCE INDUSTRY
}

\author{
Simran Kumari \\ Universal Business School, Bengaluru, Karnataka, India \\ Rajat Mehta \\ Universal Business School, Bengaluru, Karnataka, India \\ Rohit Kumar \\ Universal Business School, Bengaluru, Karnataka, India \\ Dr. Raja Roy Choudhary \\ Universal Business School, Bengaluru, Karnataka, India
}

\begin{abstract}
In this pandemic situation every person, business, and economy of the world has been devastated. This is the situation which has left a big impact on every human being. People are still trying to cope up with the new normal. People are giving their best to adapt with the situation and take all the preventive measures and getting used to it. For surviving in this world, one is finding solutions and try everything which can make their work easy.

In this research paper we will talk about the E-commerce business which is struggling in this pandemic situation. Pre - Covid and Post - Covid situations are totally different and adapting the new culture and style of working is very tough. Businesses are facing problems or going through tough times but upgrading themselves and being ready for the unforeseeable future is the test every company should pass it with flying colours.
\end{abstract}

Key words: E-commerce business, Pre - Covid and Post - Covid situations.

Cite this Article: Simran Kumari, Rajat Mehta, Rohit Kumar and Raja Roy Choudhary, Impact of Covid - 19 on Consumer Behaviour in E-Commerce Industry, International Journal of Management, 11(12), 2020, pp. 2438-2450.

http://iaeme.com/Home/issue/IJM?Volume=11\&Issue=12

\section{INTRODUCTION}

As we all are aware of the fact that people in India practice both traditional and novel ways while purchasing products. Before COVID 19 pandemic products purchased online vary from product to product. like buying furniture, medicines, edible items, electronics, grocery etc were 
preferred to purchase from physical stores. But pandemic has shifted buying all the products online.

The business of E-commerce is on boom but with different limitations like slow movement of goods, sanitizing products, less workforce, more safety measures etc. Lockdown has made people adopt modern ways while shopping and changed their buying behaviour simultaneously created trust towards online platforms. It results on change in demands of products and impacting supply of items. E-commerce industry was quick enough to understand the situation and took the possible actions.

If comparison has to be done everyone can see the changes in the buying habits of consumers both online and offline. The new normal of the world will be online platforms and kirana stores or physical stores will be in great distress. Safety of consumers is of utmost priority for every business and how E-commerce platforms understood the customer psyche by putting themselves in their shoes and quickly analysed the situation has helped the country deal with the COVID 19 situation with ease and less pressure.

It is becoming tough for companies to sell their products after a massive lockdown when no one is purchasing anything, and everything was on hold. Making accurate strategies to convince people to take out money from their pockets is the most difficult task. Accepting all the losses and then growing with all the possible solutions in the best interest of consumers considered as giving your best shot in this competitive world.

Online platforms are thriving the market and making profits unlike others. Apart from already established online platforms other businesses are making efforts to grow business online. Businesses are working to their full potential to provide their services online by keeping in mind hygiene and safety of customers.

People are trying hard to live the normal life again and businesses are trying to make it easy for consumers to feel the same independence to step out from their homes without making any second thoughts. Companies are trying their best and making new innovations which will take people closer to live their normal lives again.

The race between different online platforms is taking place like never before. Competition is rising day by day and adoption of new techniques and technologies to make business grow is common now. Covid 19 is the situation which has affected every person's life and continuing doing so. But it's up to us how we are going to deal with it.

\section{LIERATURE REVIEW}

Anam Bhatti, Hamza Akram, Hafiz Muhammad Basit, Ahmed Usman Khan, Syeda Mahwish Raza Naqvi, Muhammad Bilal has published a report in International Journal of Future Generation Communication and Networking. Title of the report is "E-commerce trends during COVID-19 Pandemic"

Covid-19 is leaving a negative impact all over the world, but the E-commerce business is growing. This situation is forcing people to use the internet, making it a habit and plays a vital role in their daily routine. Retailers in E-commerce are facing challenges like late delivery, social distancing etc. Everything is going slow, but people are still buying it because of no other option but to buy it online. There are many products which E-commerce industry is still facing problems to deliver the goods because of high demand and low supply like - hand sanitisers, masks, hand gloves, dairy products, and grocery. (Anam, et al., 2020)

Rajan Gupta, Saibal K. Pal and Gaurav Pandey has published an article in medRxiv. The title of the report is "A Comprehensive Analysis of COVID-19 Outbreak situation in India"

Growth trends of infected cases in India, impact of social distancing on the citizens of India, network analysis and mining of patterns on the patients suffering from coronavirus, predictions 
for the number of infected cases for next few days, and analyzing the strategies for uplifting lockdown in India and impact of mass events on the number of infected cases in India are being analyzed to give the governments data to mend the rules accordingly. (Rajan, et al., 2020)

India Infoline News Service has written an article on the topic "The impact of COVID - 19 on Indian E-commerce sector"

COVID-19 has impacted supply chain networks, business models and jeopardised business continuity operations. Every sector has been facing huge loses in this pandemic situation including aviation, IT, automobile etc. E-commerce industry id trying to cope with the situation. There is rise in the demand of hygiene products like toilet papers, wet wipes, floor cleaners, sanitizers etc. They are finding it hard to fulfil the demands of people and focusing on the protective measures for employees by providing protective measures. To fight this crisis business should be agile and intuitive. (Akshay, 2020)

Dr. Deepak Halan has written a blog for Retail Gurus on the topic "Impact of COVID-19 on online shopping in India"

There are two other segments which hasn't explored yet i.e. people who don't buy online and the others who are ignorant of the online shopping habits because of no data plan or smartphones availability. People should be informed about all this so they can take wise decisions in this pandemic. Online sites are getting the demands like never before and they are trying to expand the warehouse facility to fulfil all demands of consumers. E-commerce site are working on it and trying to keep the stock which is more necessary for customers right now. (Deepak, 2020)

Some news has been posted in The News written by anonymous writer named Web Desk on the topic "How will E-commerce change in India post COVID-19?"

Many industries have been facing huge loses but in this pandemic situation people are trusting E-commerce sites to fulfil their needs and wants. People are storing the household goods in advance which lead to the shortage of stock in the market. So, normal Kirana stores have made their online sites to deliver the goods up to a certain kilometre with proper sanitizing of products and options of home delivery. It is helping to cut the load of E-commerce sites from their shoulders and helping them to deliver the necessity goods to every person's house. (Desk, 2020)

Express Computer has written a report on the topic "E-Commerce witness $17 \%$ growth post COVID-19; 65\% growth in brands establishing own website"

In this pandemic situation E-commerce sites are receiving more orders with a percentage of $17 \%$. People are considering direct to consumers goods i.e. brands selling directly to consumers, significant growth in pharma, agriculture and FMCG products, rise the list of first-time online shoppers, low returns of orders etc. This throws light on the growth opportunities, changing buying patterns of consumers, detailed insights on returns and delivery. (Express Computer, 2020)

Peerzada Abrar has written an article which is being published in Business Standard on the topic "COVID-19 may lift India's E-commerce market to around $\$ 85$ billion by 2024"

There has been increase change in the behaviour of consumers which is preferring online shopping during this pandemic. Unicommerce which is a retail focussed technology platform has bought relief to online sellers. Customer buying experience has been improved by focusing on digital transformation and adoption of omni channel solutions. E-commerce sites enabling new languages so that can be easily used and understood by large audience by targeting different audience or segment group. (Peerzada, 2020) 


\section{RESEARCH ANALYSIS}

To understand the buying behaviour and change in the pattern of taking buying decisions online, the research has been conducted all over India to understand changes that are taking place in the buying behaviour of customers while purchasing products online targeting people of different age, profession and income group.

The survey has been conducted with the help of detailed questionnaire for each target group with different sample size. After getting data from the questionnaire detailed analysis has been done and used bar graphs, perpetual mapping, pie charts, statistical tools and Venn diagrams to show the results obtained.

\subsection{Objective}

The objective of the research is:

- To understand the normal buying behavior of customers

- To analyze the situation on E-commerce both pre covid and during covid

- To understand the changes taking place in the buying pattern of customers in the pandemic situation

- To know the preference of products while purchasing product online

\subsection{RSESEARCH METHODOLOGY}

We have done a primary research on the topic with the help of detailed questionnaire in the pandemic situation. We decided a certain list of questions which can fit into both before COVID and during COVID situations. The questions were easily understandable by every age group and the language used was laymen to get responses from everyone.

The questionnaire mainly contains the personal information, their profession, income, comparison of pre covid and today's scenario, payment methods adopted, priority products, issues with E-commerce etc. There were some questions which will help the E-commerce business to know what the customers are feeling and ready to spend their money in this pandemic situation.

\subsection{SAMPLE DESIGN}

The data has been collected from different cities and parts of the India. In this pandemic situation it is necessary for the E-commerce business to know the priorities of customers and to know where they are going wrong. It will help them to take steps and improve the way customers want.

Size of research -140

Location - PAN India

Timescale -15 days ( $5^{\text {th }}$ August $2020-20^{\text {th }}$ August 2020)

There are four different groups that were targeted in the research like student, businessman, business professional, home maker and others.

\subsection{DATA COLLECTION METHOD}

Primary research

- Questionnaire (Data Collection)

Secondary Research

- Literature Review 


\subsection{HYPOTHESIS}

H0 - Change in consumer behavior will be positive in adapting online platforms while purchasing products in this pandemic

H1 - Change in consumer behavior will be negative or neutral in adapting online platforms while purchasing products in this pandemic

\section{ANALYSIS}

\section{Gender of all respondents}

While filling out the online questionnaire we come across 140 people out of which there were 82 males and 58 females. So, the percentage of gender took part in providing responses for this study is:

- Males $-59 \%$

- Females $-41 \%$

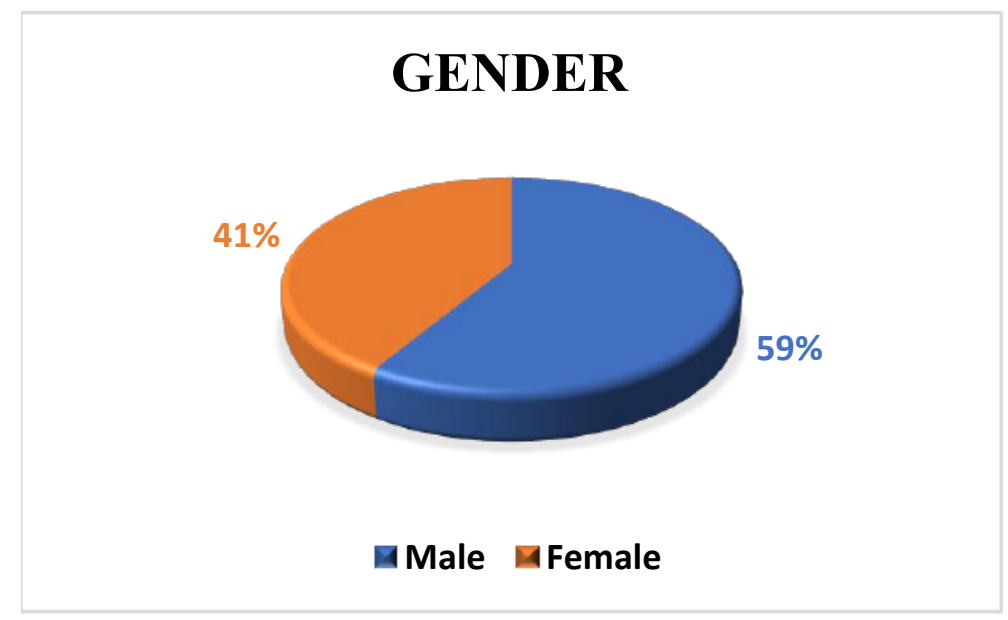

Figure 1

\section{Location of respondents}

The above picture shows the demographics of people who has spent their valuable time in providing responses for the study which almost covers every part of India. This helped us knowing the current scenario of different states and how they are dealing with this pandemic situation with online business.

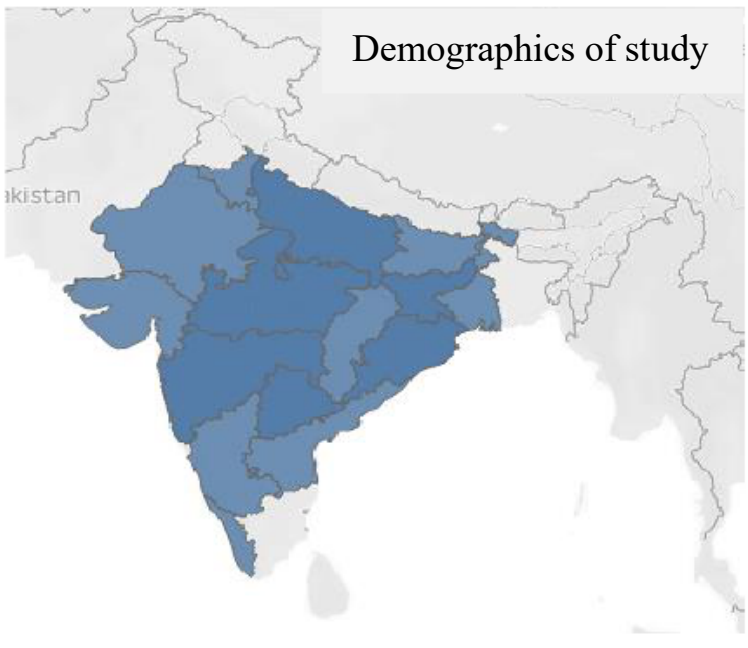

Figure 2 


\section{Age of respondents}

Most of the respondents of this questionnaire are youth of age range of 18-23. These are the people who use these E-commerce platforms the most. So, these E-commerce sites should target youths to manage the business in this pandemic.

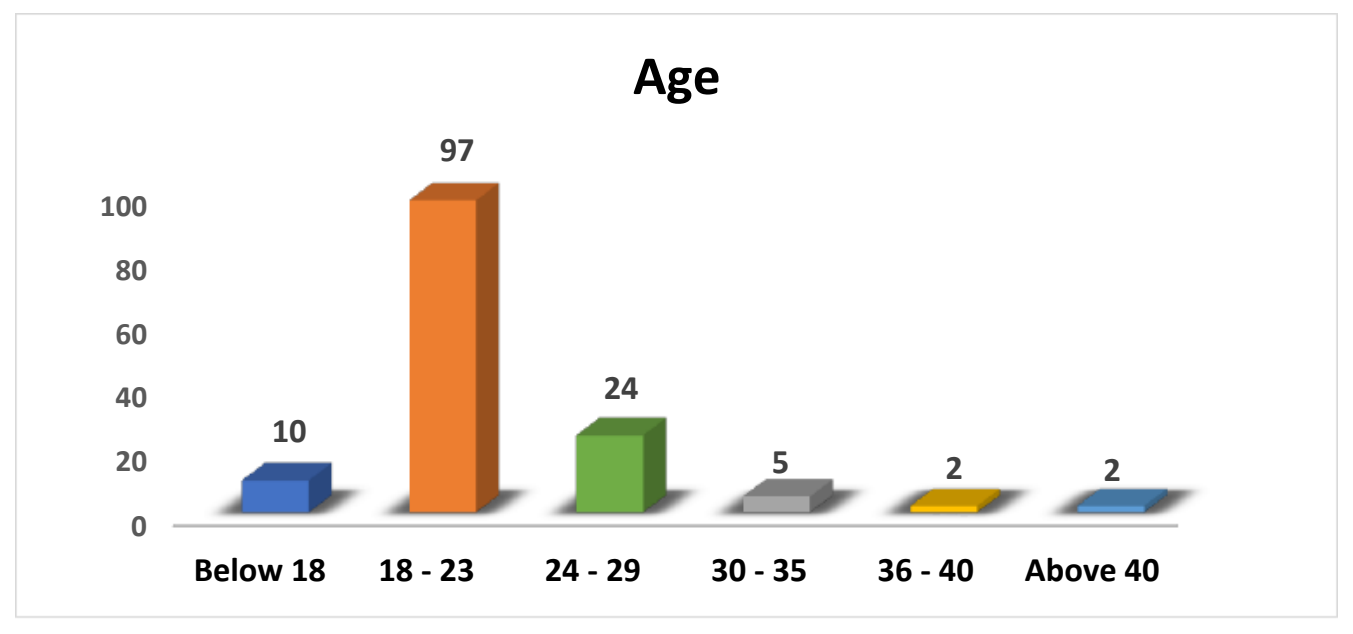

Figure 3

\section{Income group of respondents}

More than half of the respondents belongs to the income group of "Below 10k". As most of the respondents are youth, we can say that they are dependent on their parents for the pocket money and can spend only that amount of money while purchasing anything online.

\section{INCOME GROUP}

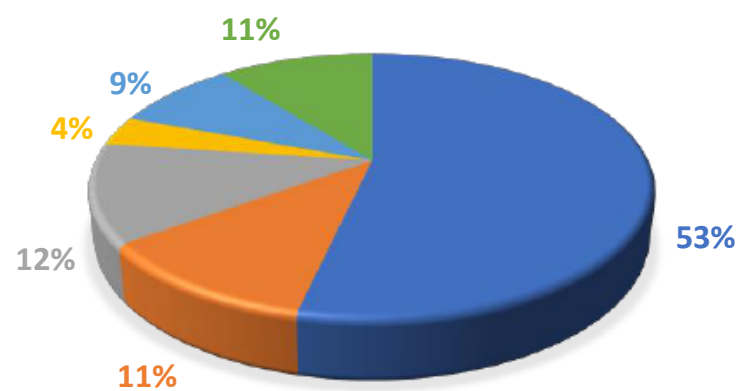

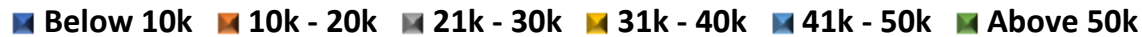

Figure 4

\section{Profession of respondents}

Most of the people who have filled this questionnaire are students. After that people who are working have participated and showed their behavior while purchasing online using Ecommerce platforms. 


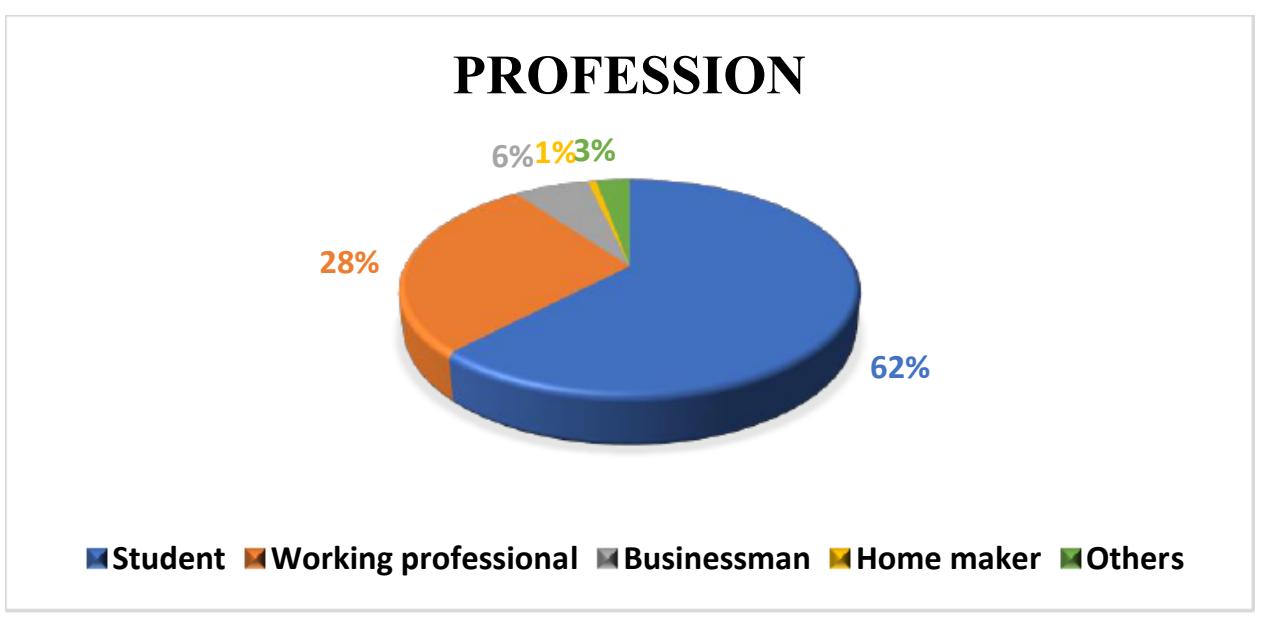

Figure 5

\section{Do you feel safe to purchase products online during this pandemic?}

The changes done by E-commerce sites after analyzing the current pandemic situation and changes in consumer behavior somehow has made people trust on these sites. The precautions they are taking for safety of consumers have made worth trusting them. Hence, people feel safe to purchase products online

\section{PEOPLE FEELING SAFE WHILE PURCHASING PRODUCT ONLINE IN PANDEMIC}

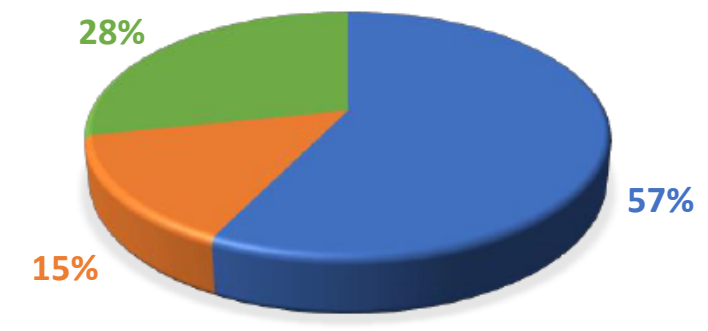

回 Yes No Maybe

Figure 6

\section{How often you have used E-commerce before and during pandemic?}

Before COVID - 19 pandemic people used to buy frequently from the E-commerce platforms. But during this pandemic there is a major downfall in using the E-commerce sites for buying products.

People are still using the E-commerce platforms but sometimes. There can be many factors involved for this downfall like - people losing jobs, safety measures, less contact with others etc. 


\section{Analysis of Use of E-Commerce}

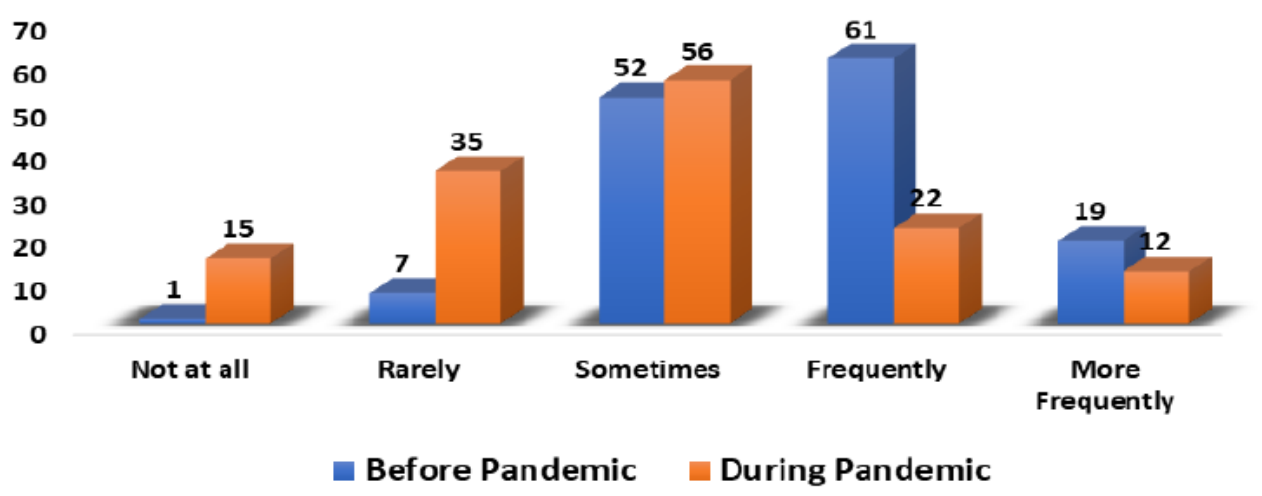

Figure 7

Products purchased in past from brick and mortar. Are you now considering it to purchase it online?

People are confused whether to purchase products online or offline because the chances or possibilities of being infected from the virus is same in both the situations. People prefer to buy products from where they used to buy before because of the trust factor

\section{SHIFT FROM BRICK AND MORTAR TO ONLINE IN COVID PANDEMIC}

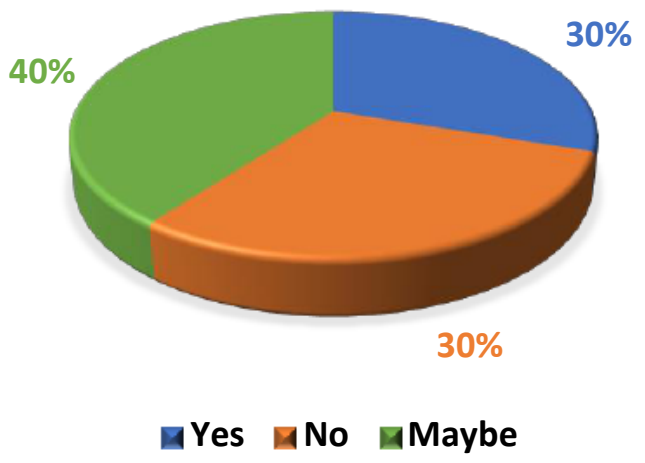

Figure 8

\section{Which E-commerce sites you use more often before and during this pandemic?}

According to the data

- Every E-commerce site is facing Downfall in their sales or orders

- Before pandemic, the most common used E-commerce sites were Amazon, Flipkart, Myntra, Paytm and Nykaa.

- After pandemic, the most common used E-commerce sites are same as that before pandemic

- People still trust the sites which they were using before COVID pandemic 


\section{E-Commerce sites Pre COVID and COVID analysis}

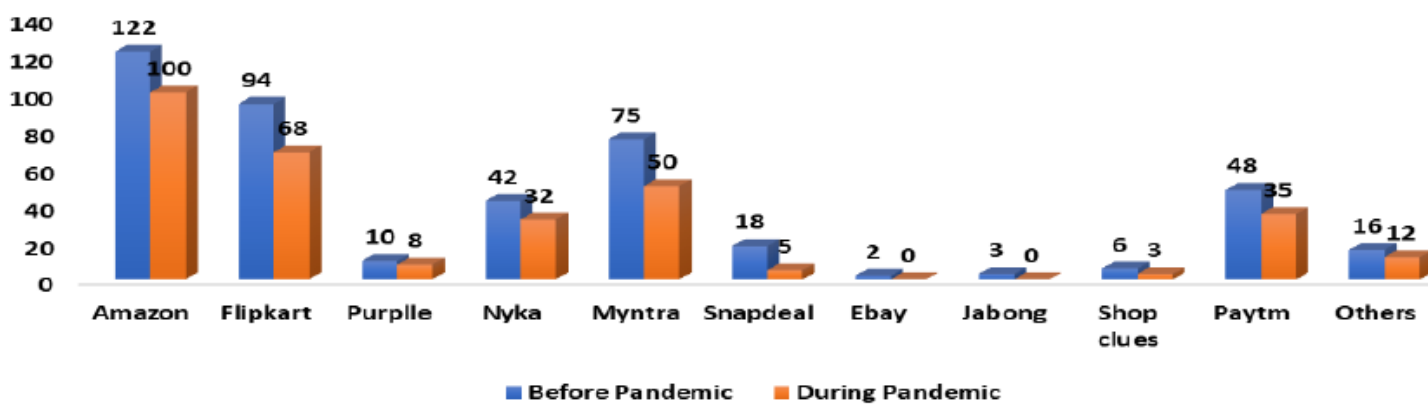

Figure 9

\section{Are you facing issues because of late delivery (no one day delivery) in this} pandemic?

In the past where people were used to one day delivery and now everything is on hold because of pandemic and from the above figure we can say that people are getting late deliveries resulting chaos in everyone's life. It all depends on the active services of different E-commerce sites in different cities.

So, $48.17 \%$ people are facing the problem of late delivery in their state or locality, $38.68 \%$ people getting their orders on time without any issues and the rest $13 \%$ sometimes face this issue and this thing don't bother them much.

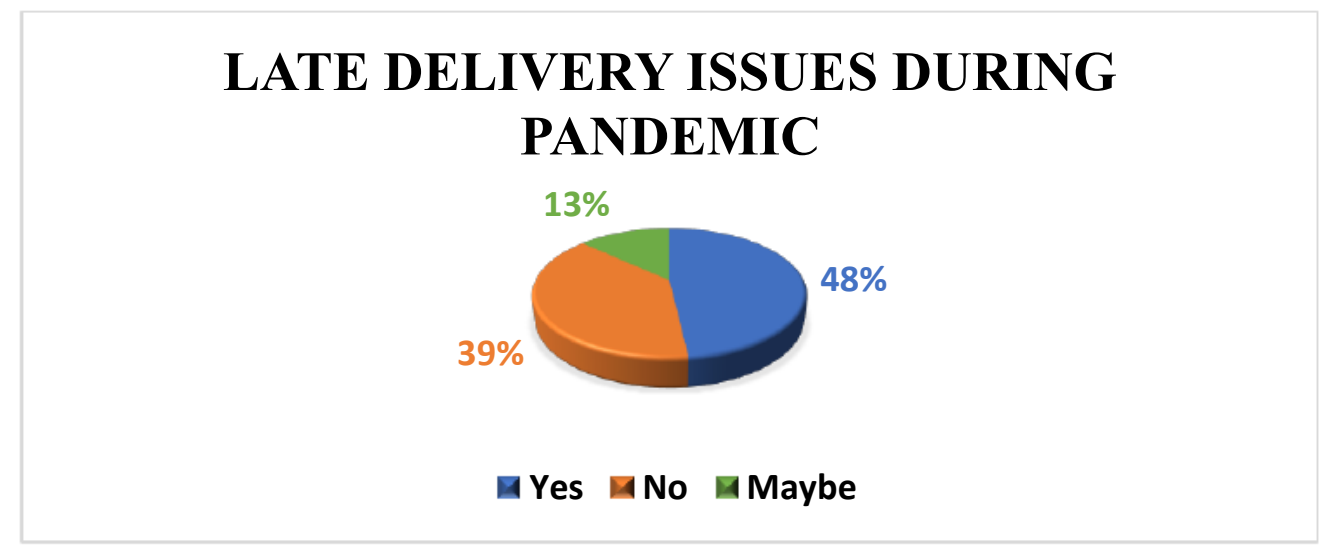

Figure 10

\section{Things you preferred buying using E-commerce sites before and during pandemic}

According to the data:

- Priorities has changed from purchasing clothes to basic necessities of house during this pandemic time frame

- To spend more time at home people are taking help of electronics as it will help most of the people to work from home too

- As physical stores were shut people were buying grocery online for the safety purpose

- Gym equipment and medicines are the things which people are spending on during the pandemic to stay fit and healthy. 
- People who used to purchase things online during Pre COVID are not buying anything because of safety measures

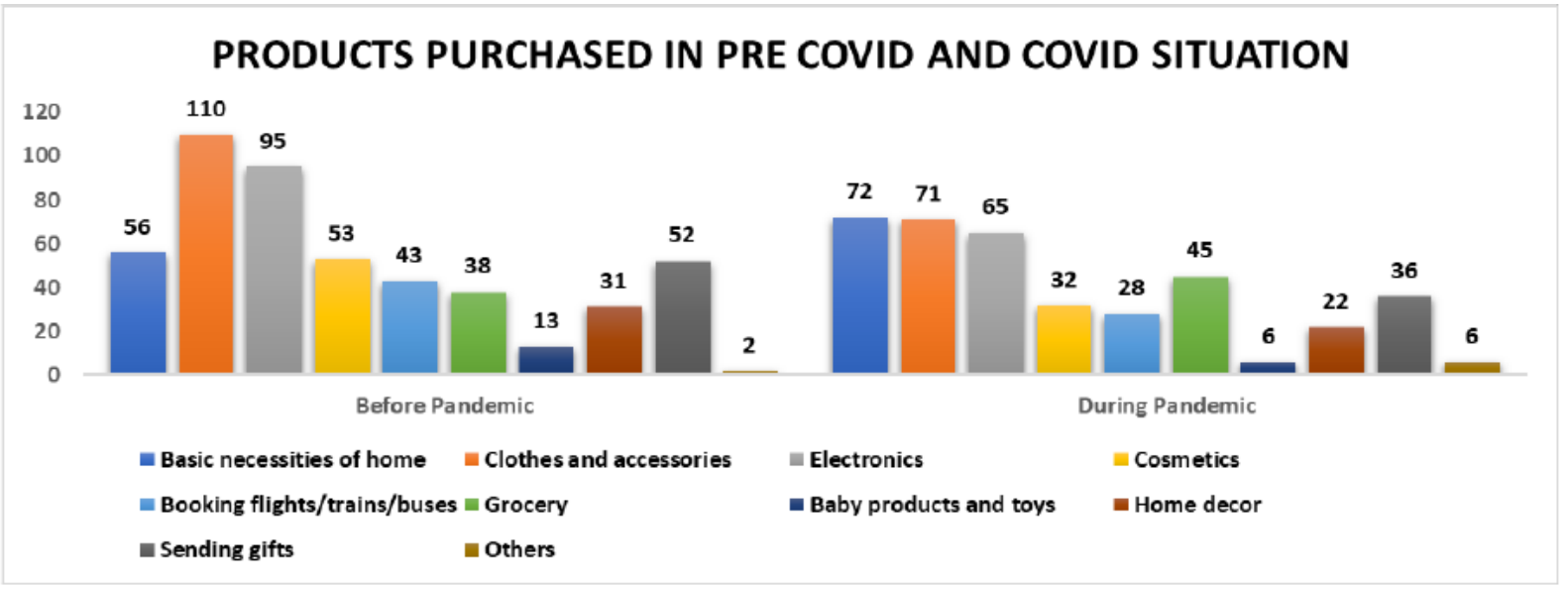

Figure 11

\section{Parameters considered while using E-commerce before and during pandemic}

According to data:

- People trusted E-commerce sites before pandemic on timely delivery, quality of products, safe payment options etc. but during pandemic every factor experienced a decrease in its rating.

- Impulse buying decreased at a very great rate during pandemic as people are more spending money on important items only

- Standards maintained for the safety of products is a big question and people believe that it is not safe to purchase products online

- People are not even purchasing products in emergency in this pandemic situation. It reflects that people are not trusting E-commerce sites and preferring Brick and motor shops.

- Green and yellow bars are rising in the pandemic situation (i.e. 1 and 2 rating). So, it shows that people are people are not leaning towards online platforms

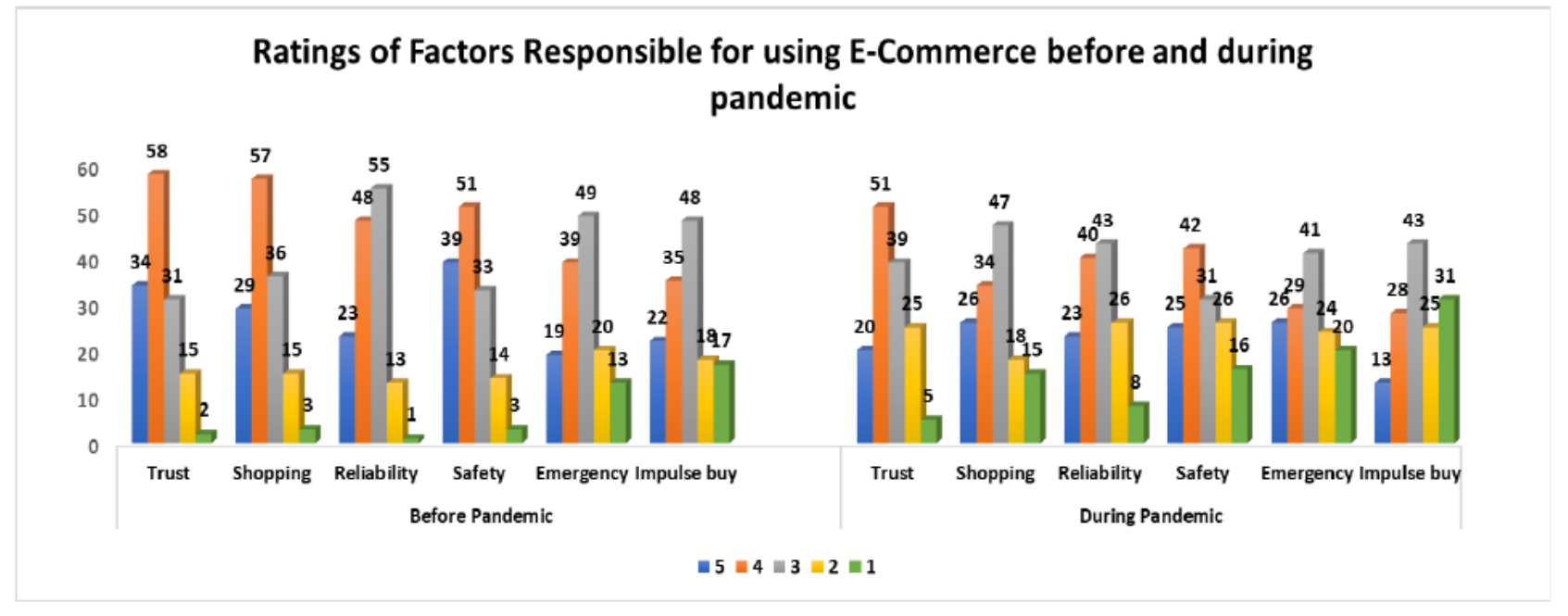

Figure 12

\section{Reasons behind using E-commerce before and during this pandemic}


According to the data:

People are best buying the products for the easy availability of goods online using various E-commerce sites

People don't care about the other features offered by E-commerce sites like:

- Discounts/offers

- Save time

- Free delivery

- Comparison of products

- Instant feedback

This pandemic situation has hit everyone so hard that people's preferences have changed and the only thing they care about is fulfilment of necessities of living

\section{Analysis of reasons behind using E-Commerce platforms}

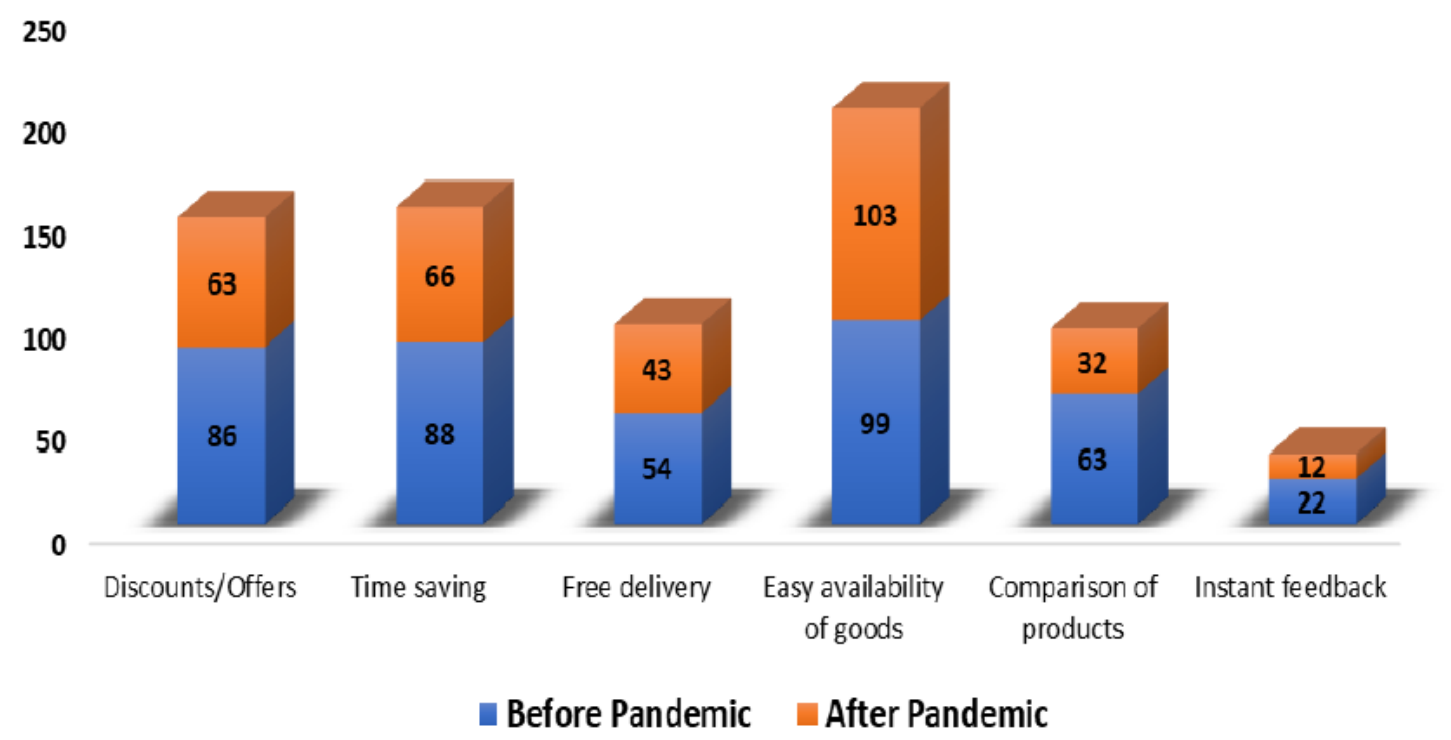

\section{Figure 13}

\section{Payment options preferred before and during this pandemic}

In this pandemic situation people are using Debit card, Credit card, E-wallets and Net banking which do not involve any type of contact. Cash on delivery reduced with $40 \%$ as people do not want to come in contact with people.

People are not caring about the fraud instead they are focusing on precautions and their health. They are more health and safety conscious. 


\section{Analysis of payment options preferred using E- Commerce sites}

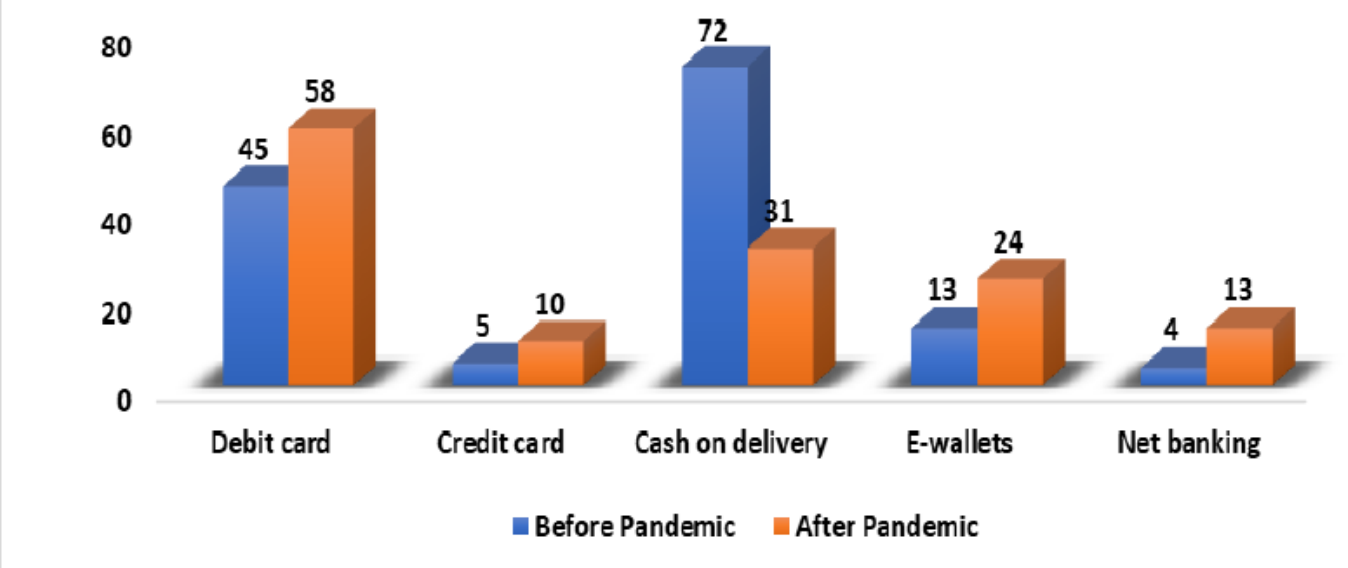

Figure 14

\section{OBSERVATIONS}

This COVID-19 pandemic has entirely changed the behavior of everyone from businesses to consumers. People are more cautious while taking any step. E-commerce industry like any other industry faced the downfall but they rise from that very quickly by keeping in mind the consumer's needs and wants.

Following are the observations:

- Meeting the demand with supply and understanding the changing consumer behavior was a bit difficult task for them.

- People are preferring the options which avoids direct contact with anything or anyone.

- People are still not ready to buy stuff online because of trust issues and fear to caught up with the disease

- E-commerce companies are facing labor issues and more safety equipments

- People are no more after discounts and offers as they now prefer quality and safety

- Demands has been changed from variety of products to the necessities of household.

- People are also leaning towards the items for the office use as everyone is now working from home

\section{RECOMMENDATIONS}

Our hypothesis regarding "change in consumer behavior will be positive in adapting online platforms while purchasing products in this pandemic" has not been proved in the research. People are not using the online platforms like they used to use before pandemic. People are not trusting both online and offline platforms while purchasing products or items.

Following are the recommendations that we want to draw after doing research:

- E-commerce sites should not think about the profits but to gain trust of people, so they complete the purchasing process

- E-commerce companies should motivate their employees to work with the same motivation as before by giving them incentives or lay out new schemes for them 
- Work on the new supply chain models so that demands can be met on time

- Make payment options as feasible as possible by providing EMI options and other things

- Make safety the priority and invest more on those materials/assets

- Should not work to survive in the market or compete but to meet the customer's needs and wants

\section{CONCLUSION}

In this research paper we will talk about the E-commerce business which is struggling in this pandemic situation. Pre - Covid and Post - Covid situations are totally different and adapting the new culture and style of working is very tough. Businesses are facing problems or going through tough times but upgrading themselves and being ready for the unforeseeable future is the test every company should pass it with flying colours.

\section{REFERENCES}

[1] Akshay, H., 2020. The impact of COVID-19 on Indian e-commerce sector. 8 April.

[2] Anam, B. et al., 2020. E-commerce trends during COVID-19 Pandemic. International Journal of Future Generation Communication and Networking, 13(2), pp. 1449-1452.

[3] Deepak, H., 2020. Retail: Economic Times. [Online] Available at: https://retail.economictimes.indiatimes.com/re-tales/impact-of-covid-19-on-online-shoppingin-india/4115 [Accessed 25 March 2020].

[4] Desk, W., 2020. News: The Week. [Online] Available at: https://www.theweek.in/news/biztech/2020/06/17/how-will-e-commerce-change-in-india-post-covid-19.html [Accessed 17 June 2020].

[5] Express Computer, 2020. E-commerce witnesses 17\% growth post COVID-19; 65\% growth in brands establishing own website: Report. 17 August.

[6] Peerzada, A., 2020. Covid-19 may lift India's e-commerce market to around $\$ 85$ billion by 2024. 27 June.

[7] Rajan, G., Saibal, K. P. \& Gaurav, P., 2020. A Comprehensive Analysis of COVID-19 Outbreak situation in India. 